\title{
Poesia POR outros meios: A PRÁtica Citacional EM Adília Lopes e Carlito Azevedo
}

Paulo Alberto da Silva SAleS*

\section{RESUMo}

Desenvolve-se uma leitura comparativa de alguns poemas da poeta portuguesa Adília Lopes e do poeta brasileiro Carlito Azevedo, na qual se evidencia uma poética citacional, híbrida e não original. Ambos possuem poemas que se servem de intertextos diversos, que vão desde citações de nomes e de apropriação de discursos à criação de hipertextos paródicos e em pastiche. Utiliza-se como corpus as obras Manhã (2015), Bandolim (2016), Estar em Casa (2018) e Dias e Dias (2020) de Adília Lopes, bem como Monodrama (2009) e Livro das postagens (2016) de Carlito Azevedo.

Palavras-chave: Adília Lopes e Carlito Azevedo. Citações. Paródia. Pastiche. Hibridismo.

A incursão pelo universo da lírica produzida nos últimos decênios, genericamente identificada pelo epíteto "contemporânea", exige de nós, leitores, astúcia e consciência a respeito dos territórios "informes" (MARTELO, 2010) pelos quais teremos que adentrar. Temos nos deparado com recentes livros de poesia cujas escritas dos poemas são intensamente marcadas por hibridismos discursivos que ressaltam a expansividade do campo poético ao se valerem, sobretudo, de citações, de colagens e de hipertextos paródicos e pastichados como principal meio de criação de poesia. A nosso ver, são poéticas que, embora deixem de lado propósitos como "novidade", "inventividade" e "revolução", trazem uma outra forma

Professor de Linguagens no Instituto Federal Goiano - Campus Hidrolândia/IF Goiano, Hidrolândia, Goiás, Brasil, e do Programa de Pós-Graduação Stricto Sensu em Língua, Literatura e Interculturalidade da Universidade Estadual de Goiás - Campus Cora Coralina/UEG, Cidade de Goiás, Goiás, Brasil.

E-mail: paulo.alberto@ifgoiano.edu.br Orcid iD: https://orcid.org/0000-0001-9980-2561 
de satisfação que também procuramos na poesia. Não à toa, como prova da ascensão dessa poética citacional, ainda no século passado, podemos citar The Wast Land, de Eliot, como uma das criações mais celebradas da poesia modernista que, por sua vez, deixaria aos poetas pós-modernos o legado de uma "poesia por outros meios" (PERLOFF, 2013).

Notadamente marcadas pelas noções de "pluralismo" e de "diversidade", poéticas atuais têm se firmado pelas visões de sujeitos ligados às temporalidades e processos de composição poética que esmaeceram os limites do poema. Constata-se, sobretudo na década de 1990 até os 2000, como destaca Moriconi (2014, p. 81), uma "vontade de abrir", tanto na poética quanto na estética e na ética prática ${ }^{1}$. Isso pode ser associado às novas feições da poesia do século 21 , que partem do princípio de abertura do verso e do próprio poema aos modos de escrita da ficção e de outras artes. Passa-se, então, a "abrir o sentido, abrir a própria língua para novas experiências de tradução, de que poetas mais jovens saem à caça, sensor à mão. Uma ideia na cabeça, uma caneta-câmera na mão, nos desvãos da linguagem" (MORICONI, 2014, p. 82). Para esse crítico, foi possível, também, abrir as noções-fetiche de "poesia brasileira", "poesia contemporânea brasileira" e na proposta deste estudo comparativista, a de "poesia contemporânea portuguesa".

Em meio a variedade de questões abordadas pelas poéticas plurais da contemporaneidade, torna-se praticamente inviável eleger um cânone representativo de alguns "estilos" ou "obras" de autores no sentido da "originalidade" e/ou de uma criação inventiva tais como as que se firmaram

Ao se deter à poesia brasileira que emergia nos anos 1990, Moriconi (2014), em Poesia e crítica, aqui e agora (ensaio de vocabulário), destaca que a entrada nas tendências da contemporaneidade poética se manifesta principalmente pelas produções de Arnaldo Antunes e de Carlito Azevedo: "Em suas dicções, o ponto de partida era uma informação referencial que tinha muito a ver com a cultura concretista. No caso de Azevedo, o diferencial, naquele seu momento de estreia, era juntar a informação concretista paulista à informação marginal carioca (esta, na prática, informação neomodernista). Um texto poético alimentado por essas duas águas era sintoma e prenúncio de que estava próximo o fim da guerra fria no campo da poesia brasileira. Com efeito, as novas gerações poéticas pós anos 80 recusaram o clima bélico que marcara desde os anos 60 as relações entre os seguidores do concretismo e o grupo identificado com o modernismo clássico dos anos 40-50" (MORICONI, 2014, p. 81). 
no alto modernismo ${ }^{2}$. Destacam-se vozes líricas emergentes por meio de poéticas "não originais", nas quais a principal característica é "[...] a citacionalidade - com sua dialética de remoção e enxerto, disjunção e conjunção, sua interpenetração de origem e destruição" (PERLOFF, 2013, p. 48). As noções de gênio e de originalidade modernas são postas à prova a partir do pensamento pós-estruturalista, sobretudo por meio dos estudos de Barthes (2004) e Foucault (2006), que anunciam a "morte do autor" como origem. Tal teoria do gênio criador e detentor dos segredos de sua obra perde sentido no poetar recente, tendo em vista que a tônica das criações dessas poéticas contemporâneas está vinculada - em uma boa parte delas, pelo menos - às práticas das citações, dos hipertextos, dos deslocamentos e dos anacronismos. Agamben (2009), por exemplo, ao tratar da noção de dispositivo em Foucault ${ }^{3}$ revela não ser mais possível constatar a produção de um sujeito real, mas sim de uma "recíproca indiferenciação entre subjetivação e dessubjetivação, da qual surge senão um sujeito espectral" (SCRAMIN; HONESKO, 2009, p. 13). Se já não é possívelver na poesia esse sujeito como uma essência - relacionada à filosofia moderna de Descartes o pensamento de Agamben (2009) sugere que haja uma desconstrução da metafísica para que surjam, então, simulacros e simulações.

$\mathrm{Na}$ miscelânea de poetas brasileiros e portugueses que adotaram alguns valores que vigoraram nos primeiros 10 anos do século XXI, tais como a complexificação, a descentralização, a replicação imperfeita e a

2 A esse respeito, Jameson (2007) contrapõe à noção de originalidade e de criação do gênio moderno os elementos constitutivos do pós-moderno, tais como "uma nova falta de profundidade, que se vê prolongada tanto na 'teoria' contemporânea quanto em toda essa cultura da imagem e do simulacro” (p. 32). Para Jameson (2007), tais diferenças significativas entre o movimento do alto modernismo e o do pós-modernismo podem ser observadas na comparação entre as obras de Van Gogh e as de Andy Warhol, uma vez que nas obras desse último nota-se "o desaparecimento do sujeito individual, ao lado de sua consequência formal" (p. 43) que inviabilizam a criação de um estilo pessoal. Resta, então, ao artista e, no caso específico da poesia, segundo Jameson, a criação de pastiches.

3 Agamben propõe, baseado nas leituras de Foucault, uma hipotética definição de dispositivo como sendo "qualquer coisa que tenha de algum modo a capacidade de capturar, orientar, determinar, interceptar, modelar, controlar e assegurar os gestos, as condutas, as opiniões e dos discursos dos seres viventes". (SCRAMIN; HONESKO, 2009, p. 12) 
porosidade (MORICONI, 2014), encontramos um profícuo diálogo entre a poesia da poeta portuguesa Adília Lopes (1960 -) e do poeta brasileiro Carlito Azevedo (1961 - $)^{4}$. Suas dicções poéticas possuem alguns traços em comum no que diz respeito às propostas de criação de uma poética citacional de/sobre leitura. Nossa aproximação entre alguns poemas de ambos se deterá, então, no exame do hibridismo de suas poéticas ao articularem elementos combinatórios de campos diversos, sejam eles signos, discursos ou intertextos da literatura canônica, da literatura de massa e de outros saberes. Nesses processos de criação da poesia de Adília e Carlito, destacamos como ambos se valem do dialogismo, da intertextualidade e do "escrever-através" que, "muitas vezes (sic) é derivada da cultura pop filmes, quadrinhos, colunas de jornal, manuais de instrução. Mas, em seu melhor estado, o texto restrito jamais replica a matéria-prima" (PERLOFF, 2013, p. 46). Aproxima-os, também, uma tendência ao multilinguismo poético, ou seja, a incorporação de línguas, vozes e variados dialetos na tessitura dos poemas. Em Adília, constatamos a predileção pelas referências a nomes, citações e transposições de frases e fragmentos pertencentes tanto a seu ambiente familiar - o espaço da casa e ambientes de Lisboa - quanto à apropriação de referências canônicas das literaturas de língua francesa e inglesa. Já em Carlito, há também menções anglófonas e francófonas, embora apareçam com maior frequência as relacionadas à cultura hispânica e, sobretudo as da América Latina, sem esquecer as emblemáticas referências aos momentos históricos cujos hipertextos paródicos as problematizam por meio dos códigos tomados emprestados.

Na poesia de Adília, desde seu primeiro livro Um jogo bastante perigoso, publicado em 1985 - integrado à obra Dobra (2014) - se verifica a presença de várias memórias discursivas e afetivas que são apresentadas por meio de um processo de ficcionalização do sujeito poético que está, por sua vez, entrelaçado a uma infinitude de intertextos, sejam eles literários

\footnotetext{
Muito embora tais poetas apresentem dicções bastantes distintas, há elos que os aproximam, principalmente no que diz respeito à preferência de ambos em fazer poesia por meio de escritos tomados emprestados e de apropriações de signos, cenas, gestos e memórias discursivas de contextos plurais. Além disso, Carlito Azevedo admite, como veremos adiante, ter parafraseado Adília Lopes em seu Livro das postagens.
} 
ou não. Associada a esses discursos, Adília recorre, também, a criação de uma poesia feita de citações e de hipertextos em forma de paródias e de pastiches, além de se apropriar de provérbios, de histórias orais e de memórias de sujeitos com os quais a poeta conviveu. Em suas mais recentes publicações, a poeta se serve, ainda, de algumas fotografias de Maria José da Silva Viana Fidalgo de Oliveira - nome civil da poeta - registradas em vários momentos de sua vida e que passaram, então, a integrar a tessitura de sua poesia discursivo-memorialística. Para visualizarmos uma das várias ocorrências desses entrecruzamentos entre o poema e outros elementos e/ ou discursos, trazemos uma dentre as várias fotografias da poeta inserida em seus livros. Essa articulação realizada por Adília nos remete diretamente à proposta dos biografemas ${ }^{5}$ apresentada por Barthes (2005). Destacamos, em especial, uma fotografia presente na obra Bandolim (2016) que reaparece na capa de Dias e Dias (2020), sua mais recente publicação:

\section{Figura 1 - PÁgina 10 do Livro Bandolim}

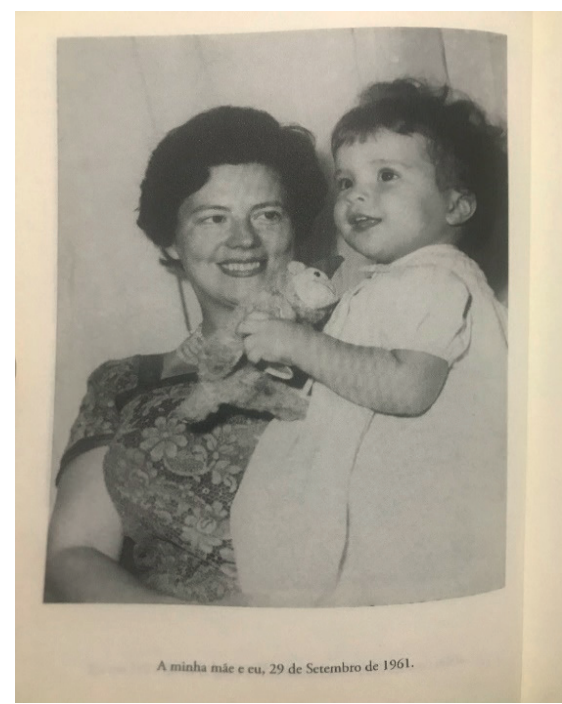

Fonte: LOPES, 2016.

Em Sade, Fourier, Loyola, a biografemática é explicada a partir da noção de prazer do texto: “[...] o autor que vem do seu texto e que vai para dentro da nossa vida não tem unidade; é um simples plural de 'encantos', o lugar de alguns pormenores tênues” (BARTHES, 2005, p. xvi). 
Já no universo poético de Carlito Azevedo, verifica-se uma semelhança à forma adotada por Adília, sobretudo no que diz respeito à poética de leitura, na qual se desenraizam os sentimentos e estes, por sua vez, cedem lugar às citações, aos pastiches, aos experimentalismos e ao hibridismo de gêneros. A mistura de discursos provenientes de diferentes contextos a uma constelação de citações aparece ligada à aproximação entre vida/arte do poeta em seu ofício laboral.

Ambos os poetas apresentam uma relação singular com o tempo contemporâneo ao aderirem a ele e, ao mesmo tempo, dele se distanciarem. É nessa relação tensa com o contemporâneo que o poeta brasileiro e a poeta portuguesa configuram seus poemas por meio de dissociações e de anacronismos. Desde a primeira obra de Carlito, Collapsus linguae, publicada em 1991, o poeta aproxima a experiência da arte e, principalmente, das memórias afetivas da infância e da juventude com uma proposta de poesia feita de memórias de leitura. Semelhante à prática de Carlito, as últimas publicações de Adília - Manhã (2015), Bandolim (2016), Estar em casa (2018) e Dias e Dias (2020) - também estão vinculadas à perspectiva do entrelaçamento das memórias discursivas com as afetivas. Nesses quatro livros, a poeta cria um estilo inconfundível de poesia que traz para o campo da lírica elementos de outros discursos, principalmente os da narrativa ficcional e, também, elementos das ciências humanas, exatas, biológicas, bem como menção aos ícones da cultura da pop art de fins do século XX. O traço comum que os une, à primeira vista, são os passos de narrativização da poesia e, por meio dessa construção, há a inserção de citações e de referências intertextuais de autores da tradição e da contemporaneidade. Os dois poemas a seguir trazem essas associações que estamos destacando. O primeiro é de Adília e pertence à obra Bandolim, publicada em $2016^{6}$. O segundo é um poema que integra

\footnotetext{
6 De todos os livros de Adília, Bandolim é, a nosso ver, aquele que apresenta maior número de poemas feitos por meio de citações, de intertextos e de hipertextos. Nele, a presença da paródia com a sua transcontextualização irônica de códigos (HUTCHEON, 1985) faz com que a poesia da portuguesa seja, como entende Perloff $(2013$, p. 46) um “[...] modo poético proeminente [de] agora é o que pode ser chamado de poética tradutória”, feita de dois polos: o multilinguismo e a escrita exofônica, ou seja, fora da voz, não fonocêntrica.
} 
o livro Monodrama, publicado em 2009. Nota-se que ambos os poemas apresentam versos que são moldados por referências diretas a textos canônicos, bem como fazem a alusão a outros artistas de outras épocas. Nessas junções, o sujeito lírico aparece de forma simulativa por meio de algumas considerações de/sobre leituras diversas:

\section{INCIPIT}

riverrun, past Eve and Adam's,

São as primeiras palavras de Finnegans Wake de Joyce. É o meu incipt favorito. Sylvia Plath diz que Adam and eve pode ter sido o nome de um bar em Dublin (The bell jar, Chapter Ten).

As duas primeiras páginas do romance de que gosto mais são as de $O$ homem sem qualidades de Musil. Fazem lembrar um relatório de física. Gostei de estudar física e ainda me lembro. Estas duas primeiras páginas são como um boletim meteorológico.

Mas é também o social que é descrito como um problema de física. Viena em Agosto de 1913 é uma experiência de física.

(LOPES, 2016, p. 55)

$1 / 6 / 15$

SOBRE PORTAS

"Atravessando cidades populosas

(como disse Walt Whitman traduzido por Konrad Tom)"

CZESLAW MILOSZ

Quando este mundo com cara de Goya (como disse Lawrence Ferlinghetti traduzido por Leminski) Dissolve sabe-se lá que matéria impura do fundo mais espesso de seu centro incandescente e ergue, batendo-as, portas de ferro contra nossas caras e pretensões democráticas, não há nuvem que não deslize 
pelo céu como uma irisada serpente de gás, não há estrela que vemos, tudo o que podemos ver por trás de nosso

humilde balcão metafísico é a hesitação do encanador e da pantera frente às duas portas

paralelas que se dublam no jogo de

espelhos das boates com as

seráficas setas do Damas

e do Cavalheiros.

(AZEVEDO, 2009, p. 70)

O poema de Adília apresenta uma leitura de alguns elementos do romance modernista Finnegans Wake, do escritor de língua inglesa James Joyce. A observação de elementos da narrativa do autor irlandês, tais como o Incipit - que também intitula o poema - fez com que o sujeito lírico se remetesse a outras impressões de leituras e a outros fatos corriqueiros que, também, se interligam a uma rede infinita de informações. Tal aspecto é muito comum nos poemas adilianos: um fato autobiográfico se interliga a um intertexto e, por meio dessa associação, criam-se autorretratos da poeta feitos de dicções irônicas. Os versos narrativizados possibilitaram com que o poema se metamorfoseasse em uma espécie de texto crítico e, ao mesmo tempo, em um parágrafo que condensa anotações e memórias afetivas. Essa discursivização das memórias textuais também aparece no poema de Carlito. Ao escolher a metáfora das portas no título do poema, que se refere à ideia de abertura e de não lugar, o sujeito poético transcreve uma fala conferida ao poeta americano Walt Whitman e que foi traduzida por Konrad Tom. Tal informação se conecta à visão de mundo do pintor realista Goya que, por sua vez, foi supostamente dita por Lawrence Ferlinghetti e, este último, traduzido por Leminski. Diferentemente de Adília, Carlito se vale de uma construção discursiva que se reverberará, também, em poemas de publicações posteriores que resgatam momentos históricos relacionados a contextos de opressão e repressão ${ }^{7}$, bem como

7 Referimo-nos a certas passagens do poema "Livro do cão", primeiro poema do Livro das postagens (2016). 
por meio de enxertos e colagens diversas, criam-se imagens conflitantes sobre as materialidades do "real" e do "metafísico" que possivelmente foram vivenciadas pelo poeta.

As figurações do sujeito lírico presentes nesses e na grande maioria dos poemas de Adília e de Carlito colocam em xeque a gênese desse eu que fala no poema que é articulado a citações e inúmeras referências intertextuais. Segundo Combe (2010), os estudos críticos anteriores à pós-modernidade opunham a noção de sujeito lírico à de sujeito "real", "autêntico" e "empírico" presentes nos gêneros autobiográficos. Contudo, as várias metamorfoses pelas quais o sujeito lírico sofreu, como também apontou Süssekind (2003), fizeram com que esse eu que fala no poema fosse o resultado da fricção entre ficção e autobiografia. Encarando, então, as evidências autobiográficas mescladas à ficção na composição do sujeito, as escrituras desses poetas criam "poemas de circunstância" na primeira pessoa endereçada que se intercalam entre citações e hipertextos.

Ainda partindo da leitura dos poemas anteriores, chama a atenção o fato de que ambos articulam propriedades discursivas que alimentam o caráter autorreflexivo da linguagem poética. Tais textos se tornam "escritura", no sentido empregado por Barthes (2010), que se mostra estelar, aberto e plural. Uma acepção aplicável à escritura e que pode ser aplicada à leitura de poemas como esses nos é dada por Perrone-Moysés (2005, p. 29, grifo nosso):

Trata-se de um conceito (abstrato) operatório que não pode nem pretende recobrir exatamente nenhuma obra ou trecho de obra concretos. Menos (ou mais?) do que um conceito, trata-se de um conjunto de traços que permitem distinguir, em determinados textos, um aspecto propriamente indefinivel como uma totalidade.

Ler um poema a partir da perspectiva da escritura é enxergar nele a não possibilidade de se criar uma totalidade. $\mathrm{O}$ texto poético se tornou autocrítico, ou seja, sua discursividade possibilita uma reflexão própria da linguagem ou da metalinguagem. Filiada à linha pós-estruturalista, a escritura marca o esvaziamento do sujeito, a renúncia de um "significado 
original" ou "verdadeiro". Na crítica tradicional ou na "velha crítica", como define Barthes (2011), havia a separação entre leitura e crítica. Com o advento das teorias da escritura e, mais especificamente, com as teorias pós-estruturalistas, uniram-se, no mesmo texto e ao mesmo tempo, a noção de ler, escrever, reler, reescrever, teorizar e criticar. Mas seria em $O$ prazer do texto que Barthes aprimoraria a teorização da escritura a partir do diálogo com Derrida (2008). Nessa obra, publicada em 1973, Barthes conceitua a escritura como jogo, simulacro, acréscimo, leitura, devir, suplemento, desejo e prazer. Essa última noção, a de prazer, tradução do francês jouissance, também seria equivalente à noção de fruição ou gozo, devido ao fato da forte influência e interpenetração da psicanálise e da análise do discurso nos estudos pós-estruturalistas. Para a leitura da poesia de Adília e de Carlito, vislumbrarmos essas marcas de crítica-escritura no tecido poético. Tratam-se de poemas feitos por meio de signos destituídos dos significados totalizantes, o que os tornam pura potência e sem quaisquer pretensões de construir um significado unívoco. Ao se valer de uma multiplicidade de discursos, a poesia de ambos parece apontar para aquilo que Siscar (2016) chamou de "fim das vanguardas" como topos das poéticas contemporâneas, tendo em vista que os poemas de Adília e de Carlito promovem indagações que extravasam o contexto e passam a questionar a sua própria natureza poética, uma vez que

[...] esse movimento, que não pode pressupor uma história acabada e linear, mas aberta a reinscrições e cruzamentos discursivos, solicita não apenas a problematização das narrativas instituídas, mas também a consciência de que a descrição de um novo contexto, qualquer que seja, nunca é saturável: ao delimitar um espaço de análise, estamos novamente aumentando sua complexidade, fazendo-o transbordar, reabrindo-o a outras perspectivas, deslocando-o necessariamente. (SISCAR, 2016, p. 12-13)

Os poemas de Adília, intitulados "Mise en abîme" e "Julia Kristeva”, pertencentes aos livros Manhã e Bandolim, respectivamente, trazem, além da intertextualidade explicita às estratégias da narrativa ficcional, 
algumas considerações teóricas de estudiosos franceses conhecidos pela crítica literária, principalmente as relacionadas à perspectiva do texto poético como récriture. Neles, é notório como a poeta articula elementos combinatórios de campos distintos, os quais se vinculam aos elementos da teoria da literatura, à autobiografia, à biografia sobre membros de sua família e a nomes de estudiosos da revista Tel Quel (1960), fundada por Phillippe Sollers. Por meio desses emaranhados discursivos, Adília, ironicamente, se insere nos poemas por meio de uma ficcionalização de si:

\section{MISE EN ABÎME}

A partir de 1975 comecei a ir à biblioteca do Instituto Francês em frente da estação de metro do Parque na António Augusto Aguiar. Era uma biblioteca de livre acesso. Isto era melhor o de tudo. De uma vez, no Verão, estava lá sozinha a ler. Um doente mental abordou-me, estava sempre a tossir. Mostrou-me um caderninho lindo cheio de rosinhas com poemas obscenos. Não, de poemas obscenos nunca gostei, não gosto nada. Eu lia por essa altura Mémoires d'une jeune fille rangée de Simone de Beauvoir. Simone de Beauvoir conta nesse livro que lhe aconteciam coisas assim nas bibliotecas públicas de Paris quando era adolescente. Simone de Beauvoir nasceu em 1908, a minha avó materna nasceu em 1901. (LOPES, 2015, p. 103)

\section{JULIA KRISTEVA}

A primeira vez que entrei na Faculdade de Letras foi no fim da minha adolescência para ouvir uma conferência de Julia Kristeva. Julia Kristeva falava francês muito depressa. Consegui perceber tudo, não tive dificuldade em acompanhar. Logo ao princí- 
pio Julia Kristeva começou a falar da teoria das catástrofes. Eu ainda não tinha estudado a teoria das catástrofes. Levantei-me e fui-me embora. Achei que era melhor ir estudar a teoria das catrástofes. Depois leria Julia Kristeva.

Eu era tão ignorante que nunca tinha ouvido falar de Phillippe Sollers. O professor que apresentou Julia Kristeva tratou-a por Madame Sollers. Por essa altura, o Paris-Match, que eu lia, falava de uma cartomante chamada Madame Soleil, vinham lá fotografias dela. Madame Sollers soou-me a Madame Soleil, mas achei muito estranho. Continuo a achar sexista apresentar Julia Kristeva como Madame Sollers. Julia Kristeva era casada com Phillippe Sollers mas não está na capa dos livros de Julia Kristeva Julia Sollers, eu nunca vi. Como intelectual, Julia Kristeva não se apresentava assim nas capas dos livros escritos por ela. Devo acrescentar: se me casar, quero usar o apelido do meu marido. Pelo código civil português actual, pode-se apresentar Philippe Sollers como Monsieur Kristeva. Eu não faço isso, não me passa pela cabeça fazer uma coisa Dessas. Parecia que estava a gozar. Só pode.

(LOPES, 2016, p. 60)

Em ambos os poemas, Adília joga com os significantes presentes nos nomes de Simone de Beauvoir, de Julia Kristeva e de Phillippe Sollers para exprimir algumas marcas subjetivas. Em "Mise in abîme", a poeta trata de uma história dentro de outra história, ou seja, uma narrativa em abismo. O poema se apresenta espelhado e reflete por meio da sobreposição de versos essa prática foi utilizada pela primeira vez pelo escritor francês André Gide (1869-1951), em seu livro Os moedeiros falsos (2009), e que foi, por sua vez, teorizada por Lucien Dällenbach (1977), em seu Le récit spéculaire: essai sur la mise en abyme. Já no poema "Julia Kristeva”, o sujeito lírico recorre às memórias à época dos estudos na Faculdade de Letras. Então, a poeta articula o nome desta teórica - que foi uma das primeiras estudiosas a teorizar a noção de intertextualidade em seu livro Introdução à semanálise (2005) - às impressões que o nome da estudiosa francesa lhe soava e dos sentidos que essa impressão lhe causava. Nota-se, em ambos 
os poemas, uma dicção risível e irônica que distorce os sentidos primeiros aos quais os poemas se referem. Não obstante, a referência explícita aos estudos de Kristeva reforça a predileção de Adília pela prática intertextual, recorrente em todos os seus livros, não só nos processos de diálogos entre textos, mas nos jogos textuais nos quais os textos são arquitetados em forma de puzzles e se valem, muitas das vezes, da articulação de nomes próprios: "Escrevo escrevo escrevo escrevo almadamente. Almadamente é o contrário de desalmadamente. E é Almada Negreiros, Nome de guerra” (LOPES, 2016, p. 129).

De maneira similar, Carlito Azevedo articula em seu Livro das postagens (2016), assim como o fez em Monodrama, a criação de uma poesia feita de citações, apropriações de falas e de pastiches. Trata-se de uma obra híbrida na qual a citacionalidade funciona como o eixo que sustenta os dois longos poemas que compõem o livro. O primeiro deles é intitulado como "O livro do cão" e o segundo, "livro das postagens", tem o título homônimo ao da obra. Neles, nota-se um questionamento acerca da autonomia da arte, da literatura e dos conhecimentos das humanidades constituídos e cristalizados até então. Tudo é desapropriado porque não há mais um território reconhecível. A imprecisão, o desajuste de imagens criadas pelos "versos" - ou seria melhor frases (?) - feitas por meio de monólogos tornam esse livro de poesia um mosaico de citações marcado pelo hibridismo e pela inespecificidade (GARRAMUÑO, 2014).

As intertextualidades aparem nesse livro de Carlito por meio da menção a nomes de poetas, de escritores, de pintores, de diretores de cinema, de fotógrafos, de jornalistas e de músicos. As referências a essas personalidades estão arquitetadas nos discursos poéticos por meio de trechos de óperas e de filmes cujas passagens possibilitam os leitores visualizarem elementos da arte cinematográfica e musical. Mediadas a essas junções, os poemas mencionam personalidades históricas de vários momentos da história política e social e, ainda, a momentos que lembram a primeira e a segunda guerras mundiais.

O segundo poema que integra o livro, também chamado de "livro das postagens" - que remete diretamente os leitores à densa obra 
Passagens, de Walter Benjamin (2009) ${ }^{8}$ - há processos de reescrituras de textos diversos. Diferentemente do primeiro poema, aqui as citações de textos literários e não literários são entrelaçadas à voz de um sujeito que está trancando em um quarto a escrever poemas e só tem contato com o mundo externo por meio das redes sociais. Na primeira da parte "livro das postagens", há a seguinte transcrição:

Figura 2 - Página 41 do LiVRo das postagens

Andrea R. postou essa foto (Facebook)

com a legenda

Eu na embaixada da Argentina

quando os exilados brasileiros

esperavam por notícias sobre

qual país iriam depois

do golpe do Chile

em 1973

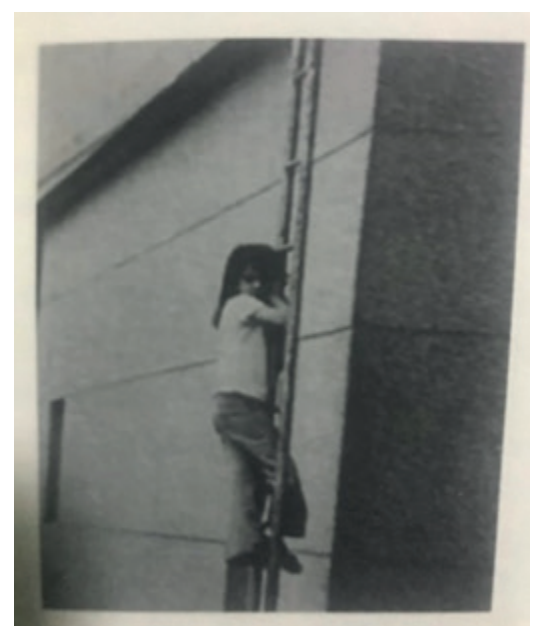

Fonte: AZEVEDO, 2016, grifo do autor.

8 Sobre os processos de escrita dessa obra, ver "Fantasmagorias do mercado: a poética citacional nas Passagens, de Walter Benjamim”, de Perloff (2013). 
As referências à postagem no Facebook e ao ano de 1973 que marca o início do governo autoritário de Augusto Pinochet (1915-2006) dialogam com a fotografia colocada em seguida. Relacionada, ainda, à fotografia, o sujeito lírico ainda menciona: "E então só consegui pensar em Z.: / esta menina está parada como a flecha de Zenão". (AZEVEDO, 2016, p. 41). A menção a Zenão de Eleia (495 a.C.- 430 a.C.) refere-se à alegoria da flecha que voa mas não voa, ou melhor, do paradoxo da flecha imóvel que analisa a pluralidade e mudança das coisas para tentar provar a impossibilidade do movimento. Esses elementos intertextuais díspares que, a princípio, não poderiam ter sentido algum - se pensarmos nos seus contextos primeiros -, na poesia de Carlito passam a exercer uma função específica: a de estranhamento no leitor. Este último é obrigado a ir para além das fronteiras entre os discursos para a atribuição de algum sentido ao que se está lendo. Mais adiante, há a seguinte passagem:

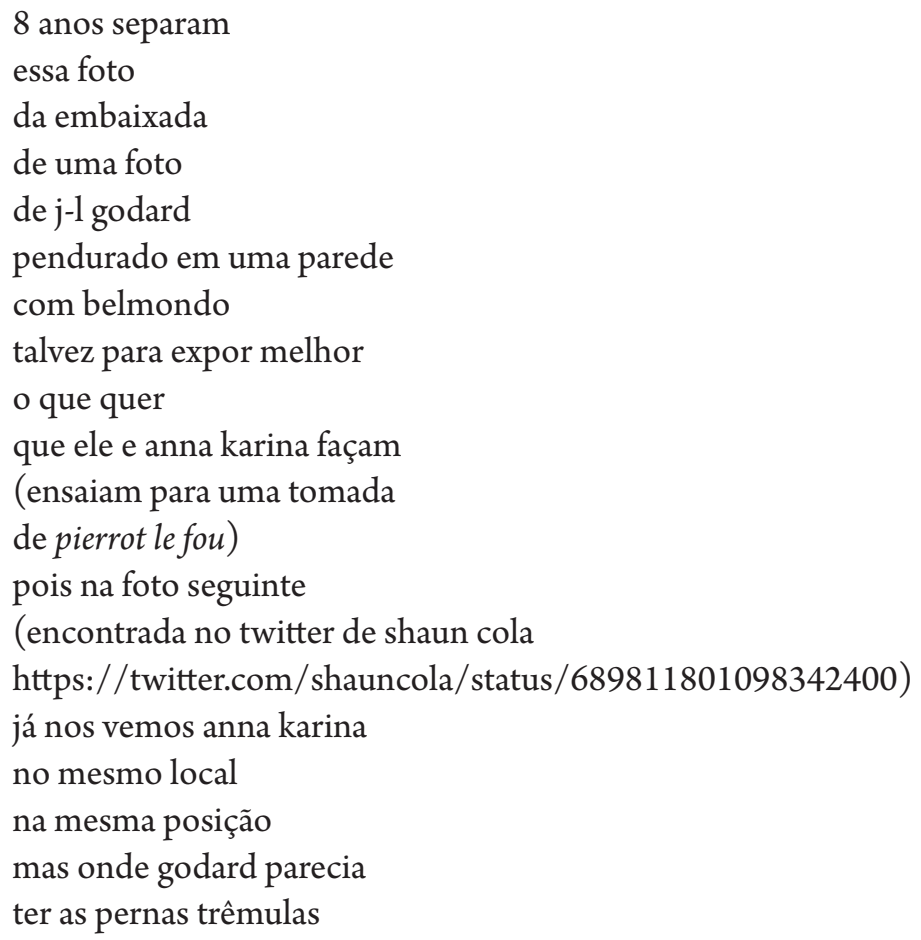


e medo de cair

anna karina paira

como uma garça

a menina na embaixada

não parece tremer

nem ter medo de cair

ainda não tem

onde cair

J-L G

em

adeus à linguagem

a sociedade está

disposta a aceitar

$o$ assassinato

como meio

de reduzir

o desemprego?

(AZEVEDO, 2016, p. 46-47, grifo do autor)

A imagem inicial da moça na embaixada aparece, agora, relacionada às lembranças que tal fotografia traz ao sujeito lírico: a de uma foto do cineasta Godard. Nota-se que um elemento intertextual, ou melhor, uma "postagem" logo remete a outra e acabam aparecendo nas redes sociais, especificamente na passagem anterior, relacionada ao Twitter. Outras postagens continuam a aparecer na obra e os elementos inespecíficos que ampliam o campo poético de Carlito fazem transparecer algumas marcas subjetivas: "a menina na embaixada/ não parece tremer/ nem tem medo de cair/ ainda não tem/ onde cair”. Mesmo muito sutil, o poeta transparece sua subjetividade por meio de uma memória discursiva e mesmo visual. Contudo, as citações, em sua perspectiva de "acomodação", tal como entende Compagnon (1996), são lugares de reconhecimento e marcam espaços de leitura. Elas sinalizam encontros por meio de reescritas de 
enxertos. As passagens presentes nas páginas 68 e 69 do poema "livro das postagens" ilustram a perspectiva da reescritura proporcionada pelas citações na poesia que deixam de lado a inventio moderna e junto a eles, propomos a leitura comparativa do poema "Espanquemos os pobres", de Adília, pertencente à Bandolim:

Shopenhauer não parava de repetir: "O objetivo de nossa existência não é a felicidade", "Só há um erro inato: aquele que consiste em crer que existimos para sermos felizes", e esta última afirmação, retomada de Nietzsche ("A vida é má e não podemos torná-la melhor"), teve um eco imenso em toda a Europa, onde serviu um pouco para tudo e até consolação ética. Basta lembrar de Ossip Mandelstan sendo deportado para a Sibéria, onde Stálin o deixaria morrer, e dizendo à sua mulher: "Quem te meteu na cabeça que você deveria ser feliz?" (In: Schopenhauer e a criação literária europeia)

"Cheer up, Charlie. You get blue like everyone..." Willy Wonka \& the Chocolate Factory (AZEVEDO, 2016, p. 68-69)

\section{ESPANQUEMOS OS POBRES!}

«Heme aquí bajo el cielo, bajo el que tengo que ganhar dinero» Claudio Rodríguez, «Um brindis por el seis de enero»

O dinheiro não existe, nunca existiu. Não é como as pedras, as pessoas, as árvores, o $\mathrm{ADN}$. É uma coisa simbólica, um tigre de papel, um papão, uma estupidez, uma tetra. É Sheltox, mata que se farta. E nunca se farta.

Para sobreviver neste mundo agora é preciso ter dinheiro. 
Não há almoços de graça. Ninguém sobrevive sem dinheiro, sem poder. Não me venham com baboseiras, é uma questão de vida ou de morte.

Espanquemos os pobres! Assommons les pauvres! Empoderemos os pobres! Escreveu Baudelaire no Le spleen de Paris no século XIX no século XXI.

(LOPES, 2016, p. 99)

Nos poemas transcritos acima, faz-se necessário destacar que a presença de uma vasta rede de citações na arquitetura dos textos reafirma o entendimento sobre a poesia como modelo de reescrita literária que nega a concepção de uma criação autoral. Por sempre apresentar elementos deslocados - enxertos nos quais há recortes específicos de falas, de nomes e de outros contextos discursivos - o poema "[...] sempre faz aparecer a relação do autor que cita com a biblioteca, assim como a dupla enunciação que resulta dessa inserção. Nela, reúnem-se as duas atividades da leitura e da escritura" (SAMOYAULT, 2008, p. 49).

No sentido de problematizar ainda mais a prática citacional no texto poético, Carlito, no poema "livro das postagens", especificamente na página 63, constrói um hipertexto em forma de pastiche que imita a escrita poética de Adília9 . Já quase no fim desse longo poema, o leitor se depara com uma passagem na qual o sujeito lírico - identificado como uma mulher - rememora aspectos de sua juventude que estão interligados a contextos de leituras, além relatar suas experiências com estudo de línguas. Como também analisado por Martelo (2010), a presença do universo infanto-juvenil na poesia adiliana é um dado importante para criação de sua palavra poética. Os leitores da poesia de Adília, ao lerem o trecho abaixo, se não soubessem que a referida passagem integra o poema "livro das postagens" de Carlito, poderiam achar que se trataria de mais

9 Na orelha final do Livro das postagens, Azevedo (2016) afirma: "No segundo [texto do livro], uma montagem, o poema é cortado a toda hora por citações, imagens, paráfrases (de Kierkegaard a Giacometti, de Godard a Adília Lopes), postagens, frases ouvidas, recebidas por carta, telegrama, e-mail e inbox". 
um poema multifacetado de Dobra (2014). Eis o trecho do poema de Carlito ao qual nos referimos:

Lá pelos meus dezenove anos

Descobri na época que lá

de estudar tooooodas as

falei com meu pai ao telefone:

e vou dar uma volta na Hungria e de húngaro! aperfeiçoa seu inglês

por isso mesmo.

família traumatizada com aquela fui morar nos

$$
\text { Estados Unidos }
$$

teria a

possibilidade

línguas do mundo

pai, vou aprender

húngaro

Minha filha, esquece esse negócio de Hungria e assim meus planos ficaram

Meu pai é húngaro, experiência...

(está um lindo dia de sol)

É muito estranha a sensação de

intimidade com uma cultura

com a qual não tenho a menor intimidade.

Toda essa história da minha família que é muito estranho.

Juro

$$
\text { que }
$$

chegou ao

Brasil só depois da guerra e portanto viveu na

Hungria a perseguição toda

É cercada de mistério! Pouco me

falaram sobre

tudo aquilo.

Só sei que daria um filme onde o piano negro de Drummond se enquadraria

perfeitamente visto que minha bisavó era exímia pianista.

E é por isso que eu fico lendo os filósofos. 
Nesse hipertexto pastichado, Carlito forja supostas memórias afetivas que imitam/lembram às da poeta portuguesa e remetem diretamente aos já citados livros Manhã, Bandolim, Estar em Casa e Dias e Dias. Como teorizado por Genette (1982), a prática imitativa do pastiche enaltece as semelhanças diretas entre o hipotexto e o hipertexto. Tal escrito de Carlito funciona, dentre outras coisas, como uma homenagem a poesia da poeta portuguesa e, tão logo, instiga os seus leitores a conhecerem as fontes utilizadas como matéria do poema.

Adília, por sua vez, articula as citações com outros diversos intertextos da tradição e da pós-modernidade que são, também, associadas às suas experiências. Lido sob essa perspectiva, o poema se apresenta possuidor de várias camadas de significado e o leitor, por sua vez, é quem deve se atentar aos jogos de sua escrita. No poema "Barthes e Schopenhauer", lemos:

\section{BARTHES E SCHOPENHAUER}

A epígrafe de Soirées de Paris, um texto póstumo de Roland/ Barthes, é de Schopenhauer. (Acho este texto de Barthes muito/ corajoso, muito honesto, nada académico, nada de modas pari-/sienses ou outras. Gosto muito deste texto.) Schopenhauer escre-/veu num papel antes de morrer: Safámo-nos bem. É a epígrafe.

$13 / 9 / 15$

(LOPES, 2016, p. 177)

Nesse poema de Adília, bem como nas citações de Schopenhauer utilizadas por Carlito, visualizam-se propostas de récriture de textos, tanto literais quanto de comentários que refletem a natureza dos escritos de pensadores do século XX. A poesia passa a se expandir para o campo dos comentários críticos e dos arquivos, o que a torna "escrevível". Aliás, a presença dos ideais barthesianos nos textos de Adília e, de certa forma, em Carlito, são evidentes. Moldados sob hipertextos paródicos e pastichados, as referências autorais desses poetas devem ser lidas de forma semelhante as que o autor de $S / Z$ dá ao seu leitor em Roland Barthes par Roland 
Barthes: "Tudo isto deve ser considerado como dito por uma personagem de romance" (BARTHES, 2003, p. 11). Nos poemas "Frases que o meu avô Raul gostava muito" e outro sem título que trata de uma hipotética citação retirada da poesia de Fernando Pessoa, fonte importante para estudo da poesia de Adília - "Sou o binómio de Newton de Fenando Pessoa" (LOPES, 2016, p. 2010) - notam-se citações, apropriações e pastiches, ou seja, imitações de estilo que evidenciam os hipotextos retomados:

\author{
FRASES QUE O MEU \\ AVÔ RAUL GOSTAVA MUITO
}

\title{
IN VIAM LONGAM SOCIETAS BONA \\ (está escrito no ex-libris)
}

«A desgraça é a pedra de toque onde se aquilatam os amigos»

Camilo Castelo Branco

18 Agosto 1861

(está escrito num azulejo Viúva Lamego)

(LOPES, 2016, p. 34)

«Alli não havia electricidade.

Porisso foi á luz de uma vela mortiça

Que li, inserto na cama,

$\mathrm{O}$ que estava à mão para ler -

A Bíblia, em portuguez, porque (coisa curiosa) eram protestantes.»

Álvaro de Campos

Neste poema de Fernando Pessoa

etectricidade rima com caridade

$3 / 5 / 15$

(LOPES, 2016, p. 44) 
Hipertextualmente, Carlito, tanto em seu Livro das postagens (2016) quanto no seu Monodrama, também cria poemas paródicos que problematizam códigos da tradição, tornando-os bivocais (BAKHTIN, 2005). Neles, não se percebe uma crítica ao hipotexto, tal como faz a paródia tradicional teorizada por Rose (1993), mas, sim, uma complexificação dos códigos retomados, uma vez que

[...] os códigos paródicos têm, afinal, de ser compartilhados para que a paródia seja compreendida como paródia. Quer a paródia se pretende subversora de cânones estabelecidos, quer força conservadora, quer vise elogiar ou humilhar o texto original, em qualquer dos casos, o leitor tem de o descodificar como paródia para que a intenção seja completamente realizada. Os leitores são co-criadores activos do texto paródico de uma maneira mais explícita, e talvez mais complexa, do que os críticos a recepção. (HUTCHEON, 1985, p. 118)

Com o intuito de partilhar os códigos ou mesmo em perceber a intenção e reconhecimento da paródia em si, bem como da ironia de que fala Hutcheon, o poema "Pequenas humilhações diárias", de Carlito, pertencente ao Monodrama, problematiza os códigos da tradição, inserindo-os em uma nova roupagem e a contextos outros que exigem do leitor astúcia no reconhecimento de sobreposições textuais e, ao mesmo tempo, que ele seja capaz de "apanhar" a voz dupla inserida nesse hipertexto:

\section{PEQUENAS HUMILHAÇÕES DIÁRIAS}

Em Síris

há meninos.

F. G. LORCA

A primeira, e disso Xerazade já sabia com respiração escassa e tudo, é acordar. O sopapo da claridade. Que nos faz, em vão, virar o rosto e tentar voltar para dentro do sonho pela farsa, a um só tempo exígua e voluptuosa, da línguagem: você corria ao redor de uma cidadela desesperado, gritando para os de dentro da cidade que um enorme perigo os ameaçava, que deviam vir com você, que você 
sabia o caminho para longe da cidadela, que bastava seguir a trilha dos ciprestes em chamas. Que louco espetáculo de luzes, pensavam as mariposas, imantadas por seu fulgor. E se no sonho o coração batia acelerado, os olhos se moviam injetados e o suor cobria a testa, agora, depois das pequenas humilhações do espelho e do dentifrício, eis você debaixo de um penteado perfeito, tirando café preto da garrafa térmica verde. Claro que vocês ouviram direito. Café preto da garrafa térmica verde. Eu, se tivesse que imaginar que somos a sitcom que alguma criança distraída nos espaços interestelares assiste de vem em quando, enfastiada ou com assiduidade de fã, julgo que a grande gag, daquelas que obrigatoriamente retornam a cada novo episódio, se dá quando todos juntos tiramos café preto da garrafa térmica verde. Sem falar na cena de fosfórico suspense para a qual não se pode pensar em trilha mais oportuna do que a música de Wiltold Lutoslawski, quando um de nós, dando-se ares de original, comenta: "eu, se não tomo o meu café preto da garrafa térmica verde de manhã, não funciono o resto do dia (risos de fita pré-gravada! Noutro plano: bombas chovem sobre a cidadela!). E uma tal besta não se dá conta de que isso está dizendo nada mais do que: "vocês para mim são pouco mais do que merda pisada e repisada porque nem me dou ao trabalho de pensar que vocês também não funcionariam sem o café preto da garrafa térmica verde, que ninguém funcionaria jamais sem o café preto da garrafa térmica verde, e anuncio a coisa como se fosse um sinal característico meu, pessoal e intranferível, como aquele trevoso sinal de nascença que tenho na nuca e que se assemelha a uma silhueta de ouriço”. Agora pensem no outro coitado, o pobrezinho de paletó puído, quase transparente, aquele num canto da mesa, esperando que lhe venha a pálida garçonete tornar a encher o copo de soda-fluo, o que diz baixinho, quando o primeiro enfim se cala, "eu parei com o café preto da garrafa térmica verde há dois meses”. Nem é orgulho, para ser justo, aquilo 
que se sente quando sussurra tal sussurro. Ao contrário do que pode parecer, é masoquismo. Sabe que todo ser vivente sob o céu dos vaticínios neste mesmo instante se dá conta perfeitamente de que foi o café preto da garrafa térmica verde que o deixou.

(AZEVEDO, 2009, p. 68-69)

Nesse sentido, por meio da leitura dos textos de Carlito e Adília, nos deparamos com uma poesia pós-lírica na qual as citações, as colagens e os hipertextos criam escritas híbridas e inespecíficas que põem em xeque a noção de poesia lírica. Muito embora a prática de fazer o novo a partir do velho seja uma das tônicas das poéticas da pós-modernidade, nas quais não se enxerga um gênio original, nota-se, contudo, uma reorganização de estilemas e rizomas que ressignificam a tradição como um todo,

[...] uma vez que concedamos que as práticas atuais da arte têm o seu próprio momento e inventio particulares, podemos desassociar a palavra original de sua parceira, a palavra gênio. Se a nova poesia "conceitual" não alega possuir qualquer originalidade - ou pelo menos não a originalidade no sentido comum - isso não quer dizer que não haja um gênio em jogo. São necessárias apenas formas distintas. (PERLOFF, 2013, p. 54)

Ao adotarem para a si a escrita poética por outros meios, Adília e Carlito são poetas cuja envergadura de seus escritos são exemplares de textos não originais, o que não significa, como bem aponta Perloff (2013), que não haja uma criação diferenciada em questão. Para vislumbrar melhor essas escritas citacionais por meio de recriações combinatórias, transcrevemos o poema "Newton e a Maçã", de Adília, no qual evidencia-se um hipertexto paródico que promove a transcontextualização de códigos de outros campos do saber e que são agregados, agora, à experiência do sujeito contemporâneo em sua palavra poética: 


\section{NEWTON E A MAÇÃ}

No ano lectivo de 1978-79, no $1 .^{\circ}$ ano do curso de Física da Faculdade de Ciências de Lisboa, na cadeira de História das Ideias em Física dada pelo Professor João Andrade e Silva, fiz um trabalho sobre Newton. Transcrevo a seguir passagens desse meu trabalho escolar:

«A primeira coisa que se costuma saber sobre Newton é a "história da maçã”. Nesta história, Newton está num pomar onde é surpreendido pela queda de uma maçã, incidente que o teria feito descobrir que "a matéria atrai matéria na razão directa das massas e no inverso do quadrado da distância”. Voltaire divulgou esta história. Tanto Mach (séc. XIX) como Papp (séc. XX), ao contrário de L.T. More (séc. XX), afirmam vivamente que esta história é uma lenda, contudo Koyré diz em "The significance of the Newtonian Synthesis", p. 302: "A famosa história segundo a qual o pensamento de Newton sobre a gravitação teria sido despertado pela queda de uma maçã parece ser perfeitamente verdadeira como foi convincentemente demonstrado por M.J. Pelseneer (Ciel et Terre 53e anée, 1937, pp. 190-193)”. Gostaria de conhecer o artigo referido, infelizmente Ciel et Terre não se encontra nos ficheiros das bibliotecas nacionais da Faculdade de Ciências de Lisboa nem nos da Biblioteca Nacional.»

Lembro-me de procurar a revista Ciel et Terre na biblioteca do departamento de Física e Matemática. Esta biblioteca ficava no Jardim Botânico, na parte romântica, no bosque, que vai até à Praça da Alegria. Foi nessa biblioteca que vi pela primeira vez fazer uma pesquisa bibliográfica num computador. Acho que foi assim. A revista Ciel et Terre existia na Universidade de Coimbra.

Transcrevo mais passagens do meu trabalho:

«Os contemporâneos de Newton achavam que ele dedicava mais tempo à interpretação do Apocalipse de S. João e da Profecias de Daniel do que ao trabalho científico.» $\mathrm{O}$ que se entendia por trabalho científico no tempo de Newton não é exactamente o que se entendia no século XX. Eu tinha consciência disso aos 18 anos. Para Newton, não devia ser disparate nenhum estudar 
durante mais tempo o livro de Daniel do que o binómio de Newton. Newton não achava que estava a perder tempo. E os contemporâneos de Newton também não, claro. Não estavam a censurar Newton.

«Nos anos da peste $(1665,1666)$, Newton deixou Cambridge e retirou-se para Woolsthorpe. As suas atividades durante estes anos prefiguram o que viriam a ser as suas obras. O célebre "binómio de Newton" foi descoberto neste período, assim como a lei da gravitação universal.»

«Ninguém percebia o que era a atracção, contudo isso deixou de ser um problema porque o sistema de Newton ia sendo comprovado pelas suas aplicações. A atracção não se tornou mais clara, mas apenas menos estranha. Mach escreveu "the uncommon incomprehensibility became a common incomprehensibility”. »

$16 / 8 / 15$

(LOPES, 2016, p. 159-160)

As intertextualidades explícitas e as citações de trechos de obras passam a constituir, textualmente, a poeta feita no/pelo texto. As várias sensações que Adília experimentou em diferentes momentos de sua infância e de sua adolescência são articuladas às suas memórias de escrita e de leitura. Para Martelo (2010), em "As armas desarmantes de Adília Lopes”, os textos de Adília são construídos de forma semelhante aos moinhos de águas passadas que a fazem rememorar - na escrita contemporânea - aos vários elementos que a constitui como poeta. Logo, são marcas inconfundíveis de sua poesia a mescla de referências literárias, artísticas e de outros campos do saber às referências autobiográficas, resultando em autofabulações de si em forma de pastiches e simulacros. Em Carlito, a infinitude de citações e referências são conectadas a diversos contextos sócio-históricos nos quais o poeta possivelmente teve contato ou, assim como Adília, por meio de sua memória discursiva, criou hiperlinks variados.

Dando cabo à nossa leitura, tendo em vista a prática da citacionalidade e as referências multivocais nos discursos poéticos dos 
poetas, aqui, tratados, somos levados a crer que a poesia de ambos tende, por meio das experimentações, a aplanar os discursos, nivelando-os. Logo, ao se valerem de citações, de enxertos, de fotografias, de fragmentos de textos em língua estrangeira e de diversos gêneros utilizados na arquitetura do poema, Adília e Carlito apresentam atos criativos distintos por outros meios e não originais.

PoEtry by Other MEANS: THe CITATIONAL PRACTICE IN AdíLIA LOPES AND Carlito Azevedo

\section{Abstract}

It is developed a comparative reading about some poems of the Portuguese poet Adília Lopes and the Brazilian poet Carlito Azevedo with the propose to identify their unoriginal, hybrid and quote poetic. Both poets have poems that use several intertexts that can be quotes of names and speech appropriation and parodic and pastiche hypertexts. As object of the study there are the works Manhã (2015), Bandolim (2016), Estar em Casa (2018) and Dias e Dias (2020), by Adília Lopes as well as Monodrama (2009) and Livro das postagens (2016), by Carlito Azevedo.

Keywords: Adília Lopes and Carlito Azevedo. Quotes. Parody. Pastiche. Hybridism.

PoESÍA POR OTRAS MANERAS: PRÁCTICA DE CITAS EN AdÍLIA LOPES Y Carlito Azevedo

\section{RESUMEN}

Se desarrolla una lectura comparativa de algunos poemas de la poeta portuguesa Adília Lopes y del poeta brasileño Carlito Azevedo en la cual se pone de relieve una poética basada en citas, híbrida y no original. Ambos poseen poemas que se valen de varios intertextos, que incluyen elementos como citas de nombres, apropiación de discursos hasta la creación de hipertextos paródicos y en pastiche. Se utilizan como corpus las obras Manhã (2015), Bandolim (2016), Estar em Casa (2018) y Dias e Dias (2020), de Adília Lopes, así como Monodrama (2009) y Livro das pastagens (2016), de Carlito Azevedo.

Palabras clave: Adília Lopes y Carlito Avezedo. Citas. Parodia. Pastiche. Hibridismo. 
REFERÊNCIAS

AGAMBEN, Giorgio. O que écontemporâneo? e outros ensaios. Tradução Vinícius Nicastro Honesko. Chapecó: Argos, 2009.

AZEVEDO, Carlito. Collapsus linguae. Rio de Janeiro: Editora LYNX, 1991.

AZEVEDO, Carlito. Livro das postagens. Rio de Janeiro: 7 Letras, 2016.

AZEVEDO, Carlito. Monodrama. Rio de Janeiro: 7 Letras, 2009.

AZEVEDO, Carlito. Sublunar. Rio de Janeiro: 7 Letras, 2001.

BAKHTIN, Mikhail. Problemas da poética de Dostoiévski. Tradução Paulo Bezerra. Rio de Janeiro: Forense Universitária, 2005.

BARTHES, Roland. A morte do autor. In: BARTHES, Roland. O rumor da língua. Tradução Mário Laranjeira. São Paulo: Martins Fontes, 2004. p. 57-64.

BARTHES, Roland. Crítica e verdade. Tradução Leyla Perrone-Moisés. São Paulo: Perspectiva, 2011.

BARTHES, Roland. O prazer do texto. Tradução J. Guinsburg. São Paulo: Perspectiva, 2010.

BARTHES, Roland. Roland Barthes por Roland Barthes. Tradução Leyla PerroneMoisés. São Paulo: Estação Liberdade, 2003.

BARTHES, Roland. Sade, Fourier, Loyola. Tradução Mário Laranjeira. São Paulo: Martins Fontes, 2005.

BENJAMIN, Walter. Passagens. Tradução Irene Aron e Cleonice Paes Barreto Mourão. Belo Horizonte: Ed. UFMG; São Paulo: Imprensa Oficial do Estado de São Paulo, 2009.

COMBE, Dominique. A referência desdobrada: o sujeito lírico entre a ficção e a autobiografia. Revista USP, São Paulo, n. 84, p. 112-128, 2010.

COMPAGNON, Antoine. O trabalho da citação. Tradução Cleonice P. B. Mourão. Belo Horizonte: Editora UFMG, 1996.

DÄLLENBACH, Lucien. Le récit speculaire : essai sur la mise en abyme. Paris: Éditions du Seuil, 1977.

DERRIDA, Jacques. Gramatologia. Tradução Miriam Chnaiderman e Renato Janine Ribeiro. São Paulo: Perspectiva, 2008. 
FOUCAULT, Michel. O que é um autor? Tradução António Fernando Cascais. Lisboa: Vega, 2006.

GARRAMUÑO, Florencia. Frutos estranhos: sobre a inespecificidade na estética contemporânea. Rio de Janeiro: Rocco, 2014.

GENETTE, Gérard. Palimpsestes. La littérature au second degré. France: Éditions du Seuil, 1982.

GIDE, André. Os moedeiros falsos. Tradução Mário Laranjeira. São Paulo: Estação Liberdade, 2009.

HOESTEREY, Ingeborg. Pastiche: cultural memory in art, film, literature. Bloomington: Indiana University Press, 2001.

HUTCHEON, Linda. Uma teoria da paródia: ensinamentos das formas de arte no século XX. Tradução Tereza Louro Pérez. Lisboa: Edições 70, 1985.

JAMESON, Fredric. Pós-modernismo: a lógica cultural do capitalismo tardio. Tradução Maria Elisa Cevasco. São Paulo: Ática, 2007.

KRISTEVA, Julia. Introdução à semanálise. Tradução Lúcia Helena França Ferraz. São Paulo: Perspectiva, 2005.

LOPES, Adília. Bandolim. Porto: Assírio \& Alvim, 2016.

LOPES, Adília. Dias e dias. Porto: Assírio \& Alvim, 2020.

LOPES, Adília. Dobra: poesia reunida (1983-2014). Porto: Assírio \& Alvim, 2014.

LOPES, Adília. Estar em casa. Porto: Assírio \& Alvim, 2018.

LOPES, Adília. Manhã. Porto: Assírio \& Alvim, 2015.

MARTELO, Rosa Maria. Poesia e des-equilíbrios. In: MARTELO, ROSA. A forma informe: leituras de poesia. Lisboa: Assírio \& Alvim, 2010. p. 9-18.

MARTELO, Rosa Maria. As armas desarmantes de Adília Lopes. In: MARTELO, ROSA. A forma informe: leituras de poesia. Lisboa: Assírio \& Alvim, 2010. p. 235-252.

MORICONI, Italo. Poesia e crítica, aqui e agora (ensaio de vocabulário). In: REZENDE, B; FINAZZI-AGRÓ, E. Possibilidades da nova escrita literária no Brasil. Rio de Janeiro: Revan, 2014.

PERLOFF, Marjorie. O gênio não original: poesia por outros meios no novo século. Tradução Adriano Scandolara. Belo Horizonte: Editora UFMG, 2013. 
PERRONE-MOISÉS, Leyla. Texto, crítica, escritura. São Paulo: Martins Fontes, 2005.

ROSE, Margaret. Parody: Ancient, Modern, and Post-modern. New York: Cambridge, 1993.

SAMOYAULT, Tiphaine. A intertextualidade. Tradução Sanda Nitrini. São Paulo: Aderaldo \& Rothschild, 2008.

SCRAMIM, Susana; HONESKO, Vinícius. Apresentação. In: AGAMBEN, Giorgio. $O$ que é contemporâneo? e outros ensaios. Tradução Vinícius Nicastro Honesko. Chapecó: Argos, 2009.

SISCAR, Marcos. De volta ao fim: o "fim das vanguardas" como questão de poesia. Rio de Janeiro: 7 Letras, 2016.

SÜSSEKIND, Flora. Ego trip: uma pequena história das metamorfoses do sujeito lírico. In: SÜSSEKIND, Flora. Papéis colados. Rio de Janeiro: Editora UFRJ, 2003. p. 305-318.

Submetido em 30 de setembro de 2020

Aceito em ?04 de dezembro de 2020

Publicado em 14 de fevereiro de 2021 